\title{
System and Legitimacy in the Wide View of Democracy
}

\section{Matthew Festenstein}

\section{(2) OpenEdition}

1 Journals

\section{Electronic version}

URL: http://journals.openedition.org/ejpap/1973

DOI: 10.4000/ejpap.1973

ISSN: 2036-4091

\section{Publisher}

Associazione Pragma

\section{Electronic reference}

Matthew Festenstein, "System and Legitimacy in the Wide View of Democracy », European Journal of Pragmatism and American Philosophy [Online], XII-1 | 2020, Online since 16 June 2020, connection on 26 June 2020. URL : http://journals.openedition.org/ejpap/1973; DOI : https://doi.org/10.4000/ejpap. 1973

This text was automatically generated on 26 June 2020 .

\section{$(\mathbb{\theta} \Theta \Theta$}

Author retains copyright and grants the European Journal of Pragmatism and American Philosophy right of first publication with the work simultaneously licensed under a Creative Commons AttributionNonCommercial-NoDerivatives 4.0 International License. 


\title{
System and Legitimacy in the Wide View of Democracy
}

\author{
Matthew Festenstein
}

Roberto Frega's Pragmatism and the Wide View of Democracy marks an ambitious attempt to construct a comprehensive and critical vision of democratic theory, a vision that draws together elements from pragmatism, from sociological theory, and from critical theory. Responding to the pervasive sense of crisis that surrounds democracy, Frega persuasively argues, requires broadening our understanding of the concept's scope. Frega seeks to move beyond two prominent conceptions of democracy in contemporary democratic theory. First, there are those who subscribe to an exclusively institutional concept of democracy (which includes most mainstream political scientists, for example) as consisting in a more or less extensive set of procedures that support popular self-rule. To the extent that this group explicitly thinks of the normative dimension of democracy at all, it does so in terms of the instrumental value of certain procedural features, such as competitive elections, the rule of law, and liberal rights of speech and association (e.g., Przeworski 2019). The other mode of thinking about democracy that Frega repudiates locates it within a philosophical ontology of the political and is more inclined to appreciate the non-instrumental value of democracy, but tends to view democracy as a special form of collective agency restricted to certain practices, actors or moments of exceptional creativity (e.g., Wolin 2016).

In their place, Frega develops a theory which is underpinned by a fusion of pragmatism, critical theory, and sociological theory. He aims to show how a "pragmatist social ontology of democracy [...] provides a solid basis for an ambitious attempt at reconstructing the whole domain of political normative theory around the concept of democracy" (63). The breadth of Frega's scholarship is impressive, as is the energy with which he engages with a wide panorama of social theorising, and I am broadly sympathetic both to the philosophical taproots of this project and to the directions in which Frega takes it. Yet this is a very ambitious project and I am concerned that it doesn't quite deliver on these ambitions in some important ways. After sketching the contours of his account, I will focus on what seem to me two important questions, 
attached to his claims about the social ontological basis of his democratic theory and to his account of the normative requirements of democracy.

3 In much of its expository detail, Frega particularly draws on an interpretation of the pragmatist tradition of thinking about social and political theory, encompassing not only the work of John Dewey but also of a range of interlocutors and near contemporaries, such as Mary Parker Follett, Charles Cooley, and Arthur Bentley. At the core of this account is the famous Deweyan claim that we need "get rid of the habit of thinking of democracy as something institutional and external and to acquire the habit of treating it as a way of personal life" (Dewey 1988 (1939): 228). This "wide view" of democracy as a way of life emphasises the everyday, social and pervasive character of democracy as well as its institutional mechanisms, viewing it as "a norm whose fields of application are not only formal political institutions but all the patterns of social interaction, the organizational forms, and the institutional arrangements that characterize a society from the micro level of primary associations to the macro level of its major social, economic and political institutions" (7). In identifying democracy with a set of everyday practices, Frega goes beyond the relatively familiar idea that democratic institutions or procedures require a certain kind of "ethos" or norms among citizens in order to be sustainable or to flourish. Rather, we should think of democracy as property of a social habits, interactions and organisations in general: the “adjective 'democratic' could and should be predicated on patterns of everyday human interaction which comply with its normative requirements" (172).

These requirements consist of three generic normative features that Frega ascribes to social interactions, namely, relational parity, inclusive authority, and social involvement. Relational parity holds when someone's position in a relationship and the specific content of her role in that relationship do not depend on her social status: for example, when the status of citizen doesn't depend on economic standing, gender or race (80). In a democratic society, there is no socially or politically privileged caste, class, gender, race, or other group, before whom others defer. Inclusive authority requires that people are the authors of the decisions whose consequences they will suffer rather than merely passive recipients of these consequences. This "all affected" principle does not mean that there cannot be hierarchy in any social decision: in the workplace, for instance, Frega allows that "hierarchical patterns of authority can be assessed in terms of their democratic quality, which in turn depends on the degree to which subordinates are involved in decision processes" (82). Social involvement refers to a social unit's capacity to involve all its members in a plurality of social practices, particularly those having to do with a common good. The value of social involvement goes beyond formal and material inclusion in decision-making authority to encompass a broader (and more diffuse) value of "unrestrained access to social practices and spaces, effective integration in social institutions such as the workplace, the neighbourhood, or the educational system" and "the concrete experience of belonging to the same social world and having a significant position in it" (83).

5 Relationships on these terms have a non-instrumental value for Frega: democracy should be pursued, he argues, not "for the sake of other, higher, ends, but is an end in itself" (69). Frega rejects not only what he calls instrumentalism, the idea that democratic processes are valued for the outcomes (say, peace or non-domination) that they deliver. He also rejects what he calls reductivism the idea that democracy is justified by reference to some other more fundamental value, such as justice or 
autonomy. Democracy should have the status of what he calls a paradigm value, one which is not valued for the sake of other values that it achieves and which acts as a kind of organising concept through which social and political life can be understood; "the added value and meaning realized by a democratic society or way of life exceeds its mere capacity to instrumentally promote other values such as justice and nondomination. It resides in realizing a self-contained form of life which is valued for its own sake" (86).

6 If these principles set the normative requirements for democracy, its social location is not restricted to a specific set of political procedures or moments of rare collective agency but comprises a broad field of practices: an overarching concept that extends "to all domains of social life, referring to the ways in which a large variety of social goods, including education, health and the quality of the environment are distributed within a society" (73-4). Here too, the relevant framework is provided through a threefold classification. Frega's discussion of his core themes is nuanced, distributed and often proceeds through an exposition of others, so in extracting some key elements of his social ontology in this way I may be over-simplifying or missing important distinctions. In essence, the idea is that the basic ingredients of a pragmatist social ontology are habits, interactions, and associational forms or organisations. Habits are dispositions to respond to the respond to the world in particular ways (231). Social interactions consist in normatively patterned sets of mutual expectations among members of a group or communicative community. Social institutions are organisations to promote or sustain specific social purposes (such as the family, firm or school):

As a social concept, democracy denotes a society in which [...] three different levels are fused together: it refers to a mode of social organization in which a specific set of habits is integrated within peculiar forms of social interaction in the structured framework of social institutions which are also organized according to democratic principles. These three dimensions interact constantly, so that the distinctively democratic quality of a social aggregate stems from the positive feedback generated by the mutual and beneficial effects of these interactions. None of these dimensions alone is sufficient for a democratic polity to exist. This complex bundle of individual habits, patterns of social interactions, and associational forms is the prime referent of a pragmatist theory of democracy. (134)

Democracy at the societal level emerges from a particular configuration of underlying democratic practice: "A given configuration of habits, patterns of interaction, and organizational forms defines the basic structure of society. A democratic society is one in which these three dimensions are weaved together in ways that are consistent with the three normative principles" (157).

Building as it does not only on pragmatism and sociology but on a wide range of critical theory literature in social and political theory, this social ontology of democracy is meant to have a critical purchase, to be something we can apply to diagnose problems with, to criticise and to revise existing practices:

Defined in these terms, the concept of democracy has the widest possible application and provides a normative standard that operates in all spheres of social life and can be used to assess the quality of any form of human association, offering guidance in diagnosing social pathologies, identifying positive models of social interaction, and devising prospective processes of social emancipation. (209)

9 Frega goes on to say that for his conception "democracy defines that form of society in which all basic institutions from the family to the state and all major organisations 
from schools to firms are organised according to the three principles" (209-10). So (a) democratic theory can't be a freestanding and purely political theory of institutions. Instead, it is built up with a psycho-social theory of habits, a sociological theory of interactions, and organizational theory of institutions specify the key ontological elements of this conception. Furthermore (b) democracy is a form of society in which all basic institutions are organised in line with the three principles. And (c) this provides a normative critical standard for the assessment of societies, their practices and institutions.

Seeing democracy as located in a multiplicity of social contexts has the advantage of drawing our attention not only to the importance of underpinning ethos and culture for sustaining democracy (a very familiar idea, as Frega accepts) but to the range of sites on which struggles for democracy can occur. The interwoven character of democracy in Frega's social ontology suggests a stronger claim. Both micro and macro institutions (a school, a democratic society) are democratic when habits, interactions and institutional forms relate to each other in the right way. We can consider Frega's argument in the light of recent thinking in democratic theory about so-called deliberative systems, which raises the same kind of issue (e.g., Dryzek 2010; Mansbridge 1999; Parkinson \& Mansbridge 2012). For a systems theorist, such as Jane Mansbridge, writing of a deliberative conception of democracy, "the criterion for good deliberation should be not that every interaction in the system exhibit mutual respect, consistency, acknowledgement, openmindedness and moral economy, but that the system reflect those goods" (Mansbridge 1999: 224). If democracy or deliberativeness is a feature that distinctively arises at the system level, then it's not the case that each part needs to be democratic:

A system here means a set of distinguishable, differentiated, but to some degree interdependent parts, often with distributed functions and a division of labor, connected in such a way as to form a complex whole. It requires both differentiation and integration among the parts. It requires some functional division of labor, so that some parts do work that others cannot do so well. And it requires some relational interdependence, so that a change in one component will bring about change in some others [...] Normatively, a systemic approach means that the system should be judged as a whole in addition to the parts being judged independently. We need to ask not only what good deliberation would be both in general and in particular settings, but also what a good deliberative system would entail. (Mansbridge et al. 2012: 4-5)

11 A systems perspective suggests that democracy at the system level requires an ordered division of labour among the different components, as well as the appropriate feedback loops (as Frega says) between them. Yet it doesn't of course require that each element of the system have the characteristics of the whole.

The significance of taking the wide view of democracy, from this holistic perspective, is that we don't restrict ourselves to delineating the supportive functions of habits, and interactions for democratic political procedures or institutions but in addition ask the normative question of the range of social habits, interactions and organisations whether or not they serve democratic functions in the wider societal context (cf. Warren 2017). There is an ambiguity in this position. One way of taking the idea that "democracy defines that form of society in which all basic institutions from the family to the state and all major organisations from schools to firms are organised according to the three principles" is that each institution needs to be organised in this way. The presence or efficacy of an organisation that fails to meet the requirements of relational 
parity, inclusive authority, and social involvement necessarily detracts from the democratic quality of the wider society. It is not obvious that this is always right. A pressure group such as Greenpeace, for example, which isn't inclusive or egalitarian in its decision-making, may contribute to improving the democratic quality of the whole by introducing ethical considerations for democratic consideration and public debate that would have been sidelined otherwise, for example, or by mobilizing a sceptical populace. Insisting on the democratisation of these institutions without other compensating changes elsewhere may diminish that societal-level democratic quality. ${ }^{1}$ On this microcosmic reading, democratic society is incompatible with any undemocratic element. Taken literally, this casts democracy as primarily a utopian ideal, not one with much purchase on any actually existing social or political form. Perhaps this is right, and we should think of democracy as primarily a utopian or ideal set of social relationships - as Dewey arguably sometimes did (Festenstein 2017). However, this doesn't seem to fit with Frega's overall methodological approach rooted in his philosophical inheritance, his project of providing a grounded and sociological approach to democratic theory: the elements of his social ontology aren't the lineaments of an ideal democratic blueprint. Rather than finding democracy in a wide range of social interactions or as an end-in-view of political action, it would mean we find it nowhere. If Frega's position is that it is only in the context of the whole being democratic that any part can be, and vice versa, he paints himself into an even narrower corner than those authors like Wolin whom he criticises for envisaging democracy as a fleeting and sporadic achievement. Democracy in this sense is very much à venir, an unachievable ideal that may regulate our current activity, at least if we (whoever "we" are) can agree on what working toward such an ideal requires of us.

On the alternative reading, democracy emerges from the interweaving of habits, interactions and organisations. To describe a society (or any selected social unit) as democratic is not to say that each organisation within it conforms to the three principles but that the society or unit does as a whole. There is a question then of how we deploy Frega's diagnostic tools, to interrogate selected institutions or to examine wider systems. If democratic pathologies are pathologies of the whole, then it is an open question whether identifying pathology in a part is more or other than identifying the ways in which it may be undermining a democratic system. So the primary critical question to ask in this case of (say) a firm, university, school, or other social institution, is not whether it is itself run in accordance with the three normative principles but whether it supports the wider society's being run in this way.

The second issue to explore concerns the normative scope of Frega's three principles. Frega doesn't really explore the sense in which democracy is meant to have noninstrumental value for everyone in pluralistic societies, including that it is constitutive of their personal self-fulfillment (127). He seems insensitive to the thought that as an everyday practice for some citizens it doesn't appear that way at all - indeed, to some of us relational equality may feel profoundly disruptive of the moral order that gives our lives meaning. Social involvement and inclusive authority are demanding and expose us to distinctive risks in our social interactions:

But for this reason perhaps someone will say that the popular state is immensely preferable to Monarchy, because in that state, in which of course everyone manages public business, everyone has been given leave to publicly display his prudence knowledge and eloquence in deliberations about matters of the greatest difficulty and importance; and because the love of praise is innate in human nature, this is 
the most attractive of all things to all those who surpass others in such talents or seem themselves to do so; but in Monarchy that road to praise is blocked. What is a disadvantage, if this is not? I will tell you. To see the proposal of a man whom we despise preferred to our own; to see our wisdom ignored before our eyes; to incur certain enmity in an uncertain struggle for empty glory; to hate and be hated because of differences of opinion (which cannot be avoided, whether we win or lose); to reveal our plans and wishes when there is no need to and to get nothing by it; to neglect our private affairs. These, I say, are disadvantages. (Hobbes 1998 [1642]: 122)

Would they be considered as disadvantages in the transformed social setting of wide democracy? And if they wouldn't, how does this matter for agents entangled in the here and now? These have been troubling questions most clearly and deeply discussed by the critical theory part of Frega's heritage (e.g., Geuss 1981).

The standard form of response to this kind of question, which is central, for example, to Habermas (1996) is that what is being justified by democratic theory at this point is specifically the legitimacy of democratic decision-making: it may be contentious or repellent for some of our conceptions of the good (and this may in turn create problems for its sustainability) but it isn't intended to be set of universal principles of social association. Rather, the idea is that, if an organisation makes its decisions informed by certain principles then its meeting these conditions provides legitimacy for the decisions it reaches, which can legitimately be taken to be binding on members, and which are underpinned by the exercise of political power.

On this standard view of democratic legitimacy, we can view Frega's three principles, of relational equality, social involvement and inclusive authority, as a set of candidate principles for a conception of democratic legitimacy, but it is not obvious that they have purchase on every social organisation, since not every organisation seeks to have the kind of binding force on its members that requires legitimation to back it up. It is not clear if the aspiration of Frega's wide view is to present a transformed and extended vision of democratic legitimacy or, more generally, of a morally justified form of society. If the former, the view seems restricted to those units that raise the normative question of legitimacy. If the latter, then it seems important to explain why this wide view has purchase in circumstances of extensive moral pluralism.

Anyone committed to understanding the challenges and promise of contemporary democratic theory will benefit hugely from engaging in depth with Frega's magisterial book. Even if it raises deep questions, this reflects the importance of the territory it covers and the vital contribution it makes to mapping that territory.

\section{BIBLIOGRAPHY}

DEWEY John, (1988 [1939]), “Creative Democracy - The Task Before Us," in J. A. Boydston (ed.), John Dewey: The Later Works, vol. 14, Carbondale, Southern Illinois University Press. 
DRYZEK John S., (2010), Foundations and Frontiers of Deliberative Governance, Oxford, Oxford University Press

FESTENSTEIN Matthew, (2017), “Ideal and Actual in Dewey's Political Theory," in S. Dieleman, D. Rondel \& C. Voparil (eds.), Pragmatism and Justice, New York, Oxford University Press

FESTENSTEIN Matthew, (2018), "Self-Censorship for Democrats," European Journal of Political Theory, 17 (3), 324-42.

FREGA Roberto, (2019), Pragmatism and the Wide View of Democracy, London, Palgrave.

GEUSs Raymond, (1981), The Idea of a Critical Theory, Cambridge, Cambridge University Press. HABERMAS Jürgen, (1996), Between Facts and Norms, transl. by William Rehg, Cambridge, MIT Press. HOBBES Thomas, (1998 [1642]), De Cive, ed. R. Tuck and M. Silverthorne, Cambridge, Cambridge University Press.

MANSBRIDGE Jane, (1999), "Everyday Talk in the Deliberative System," in S. Macedo (ed.), Deliberative Politics: Essays on Democracy and Disagreement, Oxford, Oxford University Press.

MANSBRIDGE Jane, BOHMAN James, CHAMBERS Simone, CHRISTIANO Thomas, FUNG Archon, PARKINSON John, THOMPSON Dennis F. \& Mark E. WARREN, (2012), "A Systemic Approach to Deliberative Democracy," in J. Parkinson \& J. Mansbridge (eds.), (2012), Deliberative Systems: Deliberative Democracy at the Large Scale, Oxford, Oxford University Press.

PARKINSON John \& Jane MANSBRIDGE (eds.), (2012), Deliberative Systems: Deliberative Democracy at the Large Scale, Oxford, Oxford University Press.

PRZEWORSKI Adam, (2019), Crises of Democracy, Cambridge, Cambridge University Press.

WARREN Mark E., (2017), “A Problem-Based Approach to Democratic Theory,” American Political Science Review, 111 (1), 39-53.

WoLIN Sheldon S., (2016), Fugitive Democracy and Other Essays, Princeton, Princeton University Press.

\section{NOTES}

1. In Festenstein (2018), I discuss the democratic case for the functional value of self-censorship, which also seems to fit as an instance here: habits that may threaten the flourishing of democracy may also support it.

\section{AUTHOR}

\section{MATTHEW FESTENSTEIN}

University of York

matthew.festenstein[at]york.ac.uk 